\title{
Determinants of Co-existence Between Crop Farmer and Sedentary Pastoralist's Households in Oyo and Kwara States, Nigeria
}

\author{
Festus Awoyelu ${ }^{1 *} \quad$ Ezekiel Idowu ${ }^{2}$ \\ 1.Department of Agricultural Economics, University of Nigeria, Nsukka, Enugu State, Nigeria \\ 2.Department of Agricultural Economics, Obafemi Awolowo University, Ile-Ife, Osun State, Nigeria
}

\begin{abstract}
The study examined determinant of peaceful coexistence between crop farmer and sedentary pastoralist's households in Oyo and Kwara States, Nigeria. A three-stage sampling technique was used to select 180 crop farmer and 120 sedentary pastoralist's households (300 respondents) and structured questionnaire was used to elicit data from the respondents. The data were analyzed with descriptive statistics and multinomial regression model. Results showed that $93.3 \%$ and $87.5 \%$ of crop farmers and sedentary pastoralists were no longer involved in violent conflict with each other again in the use of resources. The significant factors influencing peaceful coexistence by the respondents were age of household head, farm experience, farm size, membership of association, distance to service centers, membership of cooperative society, farm income and herd size for the two categories of respondents. Based on its findings, the study recommends a national orientation campaign to both cropper and pastoralist groups on the many benefits of their symbiotic relationship, hiring of matured herders for proper keep of animals and empowerment of local institutions to handle land matters in local areas.
\end{abstract}

Keywords: Peaceful coexistence, Resource/product exchange, Cattle entrustment contract, Calf sharing.

DOI: $10.7176 / \mathrm{JESD} / 10-12-03$

Publication date:June $30^{\text {th }} 2019$

\section{Introduction}

Inter-ethnic relations between Fulani pastoralists and Yoruba farmers have endured for centuries. The Fulani, as an economic unit, constitute one of the oldest migrant groups among the Yoruba (Olaniyi, 2014). In the 1960s, the growing migration of Fulani produced semi-permanent Fulani settlements whose leaders spoke Yoruba and mediated diplomacy with the host communities (Yoruba people) over trampled crops and farmlands (Guyer, 1997). In the past, pastoralists and crop farmers in the Sahel enjoyed peaceful interactions and a strong symbiotic relationship, although as early as the $14^{\text {th }}$ century, the historian Ibn Khaldun wrote of conflict between nomadic populations in North Africa and the peoples within emerging states (Blench, 2001). In general, however, pastoralists benefited from the grazing of crop residues such as millet straw, and crop farmers benefited from the manure droppings, which helped maintain the fertility of their cropland. These interchanges were based on pure commercial principles; pastoralists paid for the grazing of crop residues in areas with a high livestock but low crop farmer density, and crop farmers paid for pastoralists to night corral their animals in areas with a low livestock but high cropping density (Turner et al., 2012). Further interaction included a lively barter of milk for grain, and as crop farmers began keeping livestock, they gave their stock to pastoralists for herding (caretaking arrangement), and pastoralists provided the crop farmers with animals for traction.

It would be romantic, however, to imagine that relations between pastoralists and crop farmers have ever been uniformly good, in the past or present. Between 1980 and 2015 there has been an unprecedented acceleration in the frequency of violent conflicts between the two economic groups. These can be attributed to a number of causes (Awoyelu, 2017). As Tonah (2002) submits, almost everywhere in West Africa, the newly arrived Fulani pastoralists and their families are regarded as strangers, migrants and landless group (Whermann, 2008). Nonetheless, it is possible for this economic unit to integrate with the indigenous community and form a cohesive unit, as is evident from the situation in the south-west Nigeria.

The Fulani as an economic unit became a significant part of the states in southwestern and west- central Nigeria. Although competition over land and land resources existed, a profound commercial and social network existed between Yoruba and Fulani as cattle herders and traders. The two economic groups profited from each other's livelihood (Olaniyi, 2014). However, these symbiotic relationships have radically changed over the past two decades because of some economic, social, ecological, political, religious and environmental factors. The reciprocal incentives for cooperation are therefore disappearing and the relationship is turning competitive as parties vie for access to water, dry season grazing and other land resources, and crops are damaged along transhumant routes (De Haan et al., 2014).

The option of settled lifestyle of the Fulani in the southern region of Nigeria was largely informed by a number of changes in the ecological condition of the region. One of the changing conditions that made the southern/humid region of the country habitable for cattle rearing was the drastic reduction in the incidence of tsetse fly. The reduced 
incidence of tsetse fly was brought about by considerable transformation of the southern region's forest-base to derived savanna arising from continuous and expanded land clearing for agriculture and human habitation (LawalAdebowale, 2012)

Although there has been a mix of conflict and cooperation between crop farmers and pastoralists in Nigeria, conflict has been on the increase due to several economic, social, historic and environmental factors (Okeke, 2014). Dominant discourses and empirical researches tend to present interactions between these two economic units as mainly conflictive and divergent. The overriding tendency has been centered on discussions on what keeps them apart than what keeps them together. Conflict however, constitutes only one aspect of a much more complex interactions between the two groups. Their interaction may be complementary, synergistic or competitive. Complementarity occurs when one sector provides inputs to the other. In fact, there is important unexploited complementarity between crop and livestock sub-sectors of agriculture (Jabbar and Cobbina, 2013). It has even been repeatedly argued that failure to make the two groups of resource users to peacefully co-exist wastes cheap inputs (Pardee, 2008 and Guzman, 2008).

The risk of violent conflict, which can escalate into civil strife and war, negatively affects farmers and pastoralists' livelihoods. Conflict management encompasses both conflict prevention and conflict resolution to mitigate the effects of conflict. Traditionally, the response to conflict is fixed on resolution. However, the policy paradigm is shifting and there is a growing recognition that conflict prevention strategies are more effective than resolution-oriented strategies (Atta-Asamoah and Aning, 2011).

The goal of this study, therefore, is to examine determinant of peaceful coexistence between crop farmers (landowners and/or indigenous farmers) and sedentary pastoralists (migrants and/or landless group) in Oyo and Kwara States, Nigeria. The major practices adopted by these economic agents to live in peace and to enjoy sustainable livelihoods in the study area are categorized into four: resource and product exchange, entrustment contract, calves sharing and milk sharing. These practices are seen as innovations to adopt in the study. The specific objectives are to:

- describe the socioeconomic characteristics of the respondents;

- $\quad$ examine the current conflict and coexistence between the two economic agents; and

- $\quad$ analyze factors determining the choice of coexistence practices of the respondents

The study will provide planners and decision makers with useful information on how to make crop farmers and pastoralists to live together in peace for their mutual benefits. It will also assist agricultural policy makers to make extension education policy that will promote the adoption of coexistence practices as innovations in the rural areas in Nigeria.

\section{Methodology}

The study was conducted in Oyo and Kwara States, Nigeria. It covers principally the derived (wooded) savanna that is dominated by a mixture of forest and woodland interspersed with tall grasses and fire-resistant trees. The area is defined by latitude $7^{0} 01^{\prime}$ and $8^{\circ} 14^{\prime}$ and longitude $2^{\circ} 45^{\prime}$ and $4^{0} 15^{\prime}$. The coverage of the study area includes the northern part of Oyo State commonly referred to as Oyo North and southern part of Kwara State. Oyo North comprises of thirteen Local Government Areas (LGAs) while Kwara South comprises of six LGAs.

Population density in the area is relatively high and livelihood for large rural communities depends on smallholder rain-fed agriculture. The area is very suitable for crop cultivation and pastoral production. The rich pasture undergrowth is a target for extensive grazing by pastoralists. Because the region is more humid than the northern Sahel, the traditional home of the Fulani pastoralists, a large population of the pastoralists have found the region to be a home away from home and some of these have settled in the region for over five decades (Fabusoro, 2006).

Agriculture is the mainstay of the States. Crop cultivation in the area is majorly done by the indigenous Yoruba people, the Agatu and the Ebira people while pastoral production is carried out by the migrant Fulani.

\subsection{Sampling Techniques}

The target population of the study were crop farmers and sedentary pastoralists. A three-stage sampling technique was adopted for the study. First, six LGAs were purposively and proportionally chosen (four from Oyo North and two from Kwara South) based on their proximity and vegetation that favours cultivation of different types of crops and pastoral farming. The selected LGAs include Saki East, Olorunsogo, Irepo, Oorelope (in Oyo State), Moro and Asa (in Kwara State). This was followed by random selection of five farm communities from each of the six LGAs. The third stage involved random selection of six crop farmers and four sedentary pastoralists from each community. The selection procedure led to a total of 300 respondents (180 crop farmers and 120 sedentary pastoralists).

\subsection{Data Collection}

Both primary and secondary data were used for the study. The primary data were collected with the aid of 
structured questionnaire. Data collected include: socioeconomic characteristics of the respondents, current issues of conflict and peaceful coexistence between the two sets of economic agents. Secondary data were obtained from the internet and published literature.

\subsection{Data Analysis Techniques}

The results of the socioeconomic characteristics of the respondents and the current conflict and coexistence between the agents are presented in tabular form using descriptive statistics tools like frequency distribution, percentages and means.

The multinomial regression model was used to analyze factors determining coexistence practices adopted by the respondents. Four major coexistence practices were hypothesized. These include: resource/products exchange, cattle entrustment contract, calf sharing, and milk sharing. Milk sharing was taken as the base outcome. Multinomial model was used to assess the effects of the independent variables on the probability of the respondents' adoption of a practice option.

Thus, a multinomial logit model from Greene (2008) was used for the analysis. Therefore, let Yij be the indicator variable so that:

$$
\mathrm{P}\left(\mathrm{Y}_{i j}=\mathrm{j}\right)=\frac{\exp (\beta \mathrm{j} \mathrm{Xi})}{\sum_{k=1}^{J} \exp (\beta \mathrm{jXi})}
$$

where $\operatorname{Pr}(\mathrm{j})$ is the probability that the $\mathrm{i}$-th household prefers and practices the $\mathrm{j}$-th option $(\mathrm{j}=0,1, \ldots \ldots . ., \mathrm{J})$.

The respondents were asked whether they had cohabited with each other during the last five years and if yes, which option(s) they practiced and preferred most. The model was estimated with four options, namely: resource/products exchange $(J=1)$, cattle entrustment contract $(J=2)$, calves sharing $(J=3)$ and milk sharing $(J$ =4). The fourth option $(\mathrm{J}=4)$ was taken as the reference choice. $X_{i}$ represents a vector of socioeconomic characteristics of the respondents. $\mathrm{B}_{\mathrm{js}}$ are the vectors of parameters that were estimated.

Normalization of the alternatives by one of the categories $\left(\beta_{\mathrm{k}}=0\right)$ yields the multinomial logit model as:

$$
\mathrm{P}\left(\mathrm{Y}_{\mathrm{ij}}=\mathrm{j}\right)=\frac{\exp (\beta j X i)}{1+\sum_{k=1}^{J} \exp (\beta j X i)} \text { for } \mathrm{j}=1,2, \ldots, \mathrm{J}
$$

The probability of omitted ( $j$-th) alternative can be derived from the formula:

$$
\mathrm{P}\left(\mathrm{Y}_{\mathrm{ij}}=\mathrm{j}\right)=\frac{1}{1+\sum_{k=1}^{J} \exp (\beta j X i)}
$$

\section{Results and Discussion}

Socioeconomic characteristics of an individual can enhance his decision to adopt practices that can improve his production. They help to shape the entrepreneurial abilities of farmers in rational decision making (Shu'aib, 2009). The result of the socioeconomic characteristics of the respondents is presented in Table 1 . The table shows that the mean ages of the respondents were 55 and 53 years respectively. Majority of the respondents are above age 50 years $(73.3 \%$ and $71.7 \%)$ of crop farmers and sedentary pastoralists respectively. This is the general pattern of the Nigerian farming environment, its ageing population. The finding reveals that males dominate the population of the two sets of the respondents. The dominance of male rural farmers and herders could be attributed to the labour requirements in both farming and herding activities which are labour intensive and require the effort which could be provided by male farmers and herders. The respondent crop farmers in the study area claimed ownership of the community land and that the sedentary pastoralists are their tenants. This finding is in line with the patrilineal land tenure structure in Western Nigeria, a position noted by Idowu (2015). The average household sizes are 10 and 11 persons respectively. Family labour plays a significant role in the farm labour supply in the traditional agricultural production (Sule et al., 2002). 
Table 1. Socioeconomic Characteristics of the Respondents $(\mathrm{CF}=180, \mathrm{SP}=120)$

\begin{tabular}{|c|c|c|c|c|c|}
\hline \multirow[t]{2}{*}{ Variable } & \multirow[t]{2}{*}{ Years } & \multicolumn{2}{|c|}{ Crop Farmers } & \multicolumn{2}{|c|}{ Sedentary Pastoralists } \\
\hline & & Frequency & Percentage & Frequency & Percentage \\
\hline \multirow[t]{5}{*}{ AGE } & $31-40$ & 16 & 8.9 & 10 & 8.3 \\
\hline & $41-50$ & 32 & 17.8 & 24 & 20.0 \\
\hline & $51-60$ & 104 & 57.7 & 68 & 56.7 \\
\hline & $>60$ & 28 & 15.6 & 18 & 15.0 \\
\hline & Mean & & 55 & & 53 \\
\hline \multirow[t]{2}{*}{ Sex of $\mathrm{HH}$} & Male & 176 & 97.8 & 120 & 100.0 \\
\hline & Female & 4 & 2.2 & 0 & 0.0 \\
\hline \multirow[t]{5}{*}{ Household size } & $0-5$ & 18 & 10.0 & 10 & 8.3 \\
\hline & $6-10$ & 128 & 71.1 & 94 & 78.3 \\
\hline & $11-15$ & 30 & 16.7 & 8 & 6.7 \\
\hline & $>15$ & 4 & 2.2 & 8 & 6.7 \\
\hline & Mean & & 10 & & 11 \\
\hline \multirow[t]{5}{*}{ Work Experience } & $1-10$ & 26 & 14.4 & 14 & 11.7 \\
\hline & $11-20$ & 34 & 18.9 & 24 & 20.0 \\
\hline & $21-30$ & 98 & 54.4 & 66 & 55.0 \\
\hline & $>30$ & 22 & 12.3 & 16 & 13.3 \\
\hline & Mean & & 26 & & 24 \\
\hline \multirow[t]{5}{*}{ Farm size (Ha) } & $0-5$ & 20 & \multirow{5}{*}{$\begin{array}{l}\text { Herd } \\
\text { count) }\end{array}$} & $25-50$ & $10.0 \%$ \\
\hline & $6-10$ & 78 & & $51-75$ & $21.7 \%$ \\
\hline & $11-15$ & 16 & & $76-100$ & $25.0 \%$ \\
\hline & $>15$ & 6 & & $101-125$ & $38.3 \%$ \\
\hline & Mean & 9.8 & & $\begin{array}{l}>125 \\
\text { Mean } 122\end{array}$ & $5.0 \%$ \\
\hline \multirow{2}{*}{$\begin{array}{l}\text { Membership } \\
\text { Association }\end{array}$} & Yes & 154 & 85.6 & 108 & 90.0 \\
\hline & No & 26 & 14.4 & 12 & 10.0 \\
\hline \multirow[t]{4}{*}{ Level of Education } & No formal & 122 & 67.8 & 106 & 88.3 \\
\hline & Primary & 44 & 24.4 & 14 & 11.7 \\
\hline & Secondary & 14 & 7.8 & 0 & 0.0 \\
\hline & Residency & & & & \\
\hline \multirow[t]{3}{*}{ Residency } & $1-10$ & N/A & N/A & 24 & 20.0 \\
\hline & $11-20$ & $\mathrm{~N} / \mathrm{A}$ & $\mathrm{N} / \mathrm{A}$ & 88 & 73.3 \\
\hline & $>20$ & $\mathrm{~N} / \mathrm{A}$ & $\mathrm{N} / \mathrm{A}$ & 8 & 6.7 \\
\hline \multirow[t]{4}{*}{ Farm Income (N'000) } & $100-150$ & 48 & 26.7 & 4 & 3.3 \\
\hline & $151-200$ & 92 & 51.1 & 18 & 15.0 \\
\hline & $201-250$ & 22 & 12.2 & 21 & \begin{tabular}{|l|}
17.5 \\
\end{tabular} \\
\hline & $>250$ & 18 & 10.0 & 77 & 64.2 \\
\hline
\end{tabular}

Source: Field survey, 2018

The average year of farming and herding experience are 26 and 24 years respectively. This suggests that the farmers and sedentary pastoralists in the study area have long experience. It was reported by Adah and Obinne (2015) that experience comes with time and has proven to be great advantage especially as the level of mastery increases with it. The average farm size of the crop farmers was 9.8 hectares while the average number of livestock of the sedentary pastoralists was 122 herds (comprising cattle, sheep and goats). Farm size and herd size are indicative of wealth and income which in turn are highly related to the possibility of operating business under a peaceful environment. Majority of the respondents $(86 \%$ and $90 \%)$ respectively belong to one association or the other. Farmers or herders who are members of clubs/associations are better informed than those who operate alone. They are also easily traceable should conflict occur. About $80 \%$ of the sedentary pastoralists have been resident in their respective communities for more than ten years and to the extent that most of them speak Yoruba very fluently. Majority of the respondents $(67.8 \%$ and $88.3 \%)$ respectively have no formal education. Although education is very important to understand and manage the environment in which one operates, it is assumed that both economic units in this study had acquired skills in their businesses since they have long years of working experience. They also have learnt to peacefully cohabit.

3.1 Conflict and peaceful Co-existence between Crop Farmers and Sedentary Pastoralists

Conflict in resource use is not uncommon and perhaps not unnatural in human ecosystems. Conflict per se, is not 
bad; it is perhaps a necessity in the evolution and development of human organizations. In terms of struggle for scarce resources, conflict is generally seen as a situation in which two or more parties (e.g. crop farmers and pastoralists) strive to acquire the same scarce resources (land, water, and pastures) at the same time (Wellesteen, 2002). It arises from the interaction of individuals who have partly incompatible ends, in which the ability of one actor to gain his ends depends to an important degree on the choices or decisions another actor will take.

The result of descriptive analysis of conflict and peaceful co-existence conditions between crop farmers and sedentary pastoralists in the study area is presented in Table 2. Majority of the respondents (93\% and $87.5 \%)$ respectively in the study area no longer engage in violent and destructive conflicts over resource use. This finding

Table 2: Present Conflict and Co-existence condition between Crop Farmers and Sedentary Pastoralists

\begin{tabular}{|c|c|c|c|c|}
\hline Variable & \multicolumn{2}{|c|}{ Crop Farmers } & \multicolumn{2}{|c|}{ Sedentary Pastoralists } \\
\hline Involvement in conflict & 12 & 6.7 & 15 & 12.5 \\
\hline Non-involvement & 168 & 93.3 & 105 & 87.5 \\
\hline Total & 180 & 100.0 & 120 & 100.0 \\
\hline
\end{tabular}

Source: Field survey, 2018

suggests that these two economic units now enjoy mutual benefits in the sharing of natural resources perhaps after some initial period of mistrust, manifestation of hostilities, social friction and conflict. This finding is also noted by Fasona et al., (2016). The settlement of sedentary pastoralists in the study area and their eventual peaceful cohabitation with crop farmers (the hosts) could be attributed to some reasons: strict adherence to the handling of cattle grazing by mature herders, availability of veterinary medicine, all-year-round availability of pasture, symbiotic and synergistic relationship, low cattle population densities, proximity to markets, intermarriages and the need to establish reciprocal relations with the host population.

During qualitative survey, though conflict sometimes occurs, such conflict does not escalate into destruction of human lives and properties. When conflict arises, community heads and leaders of the Fulani herdsmen quickly find solution to the problem.

\subsection{Determinants of Co-existence practices adopted by Crop Farmers}

Results of the multinomial analysis of co-existence practices adopted by the sampled crop farmers to live in peace with the sedentary pastoralists are presented in Table 3. Of the four co-existence practices: resources/products exchange, cattle entrustment contract, calves sharing and milk sharing practiced by the crop farmers with the sedentary pastoralists in the study area, milk sharing is taken as a base for comparison. 
Table 3: Results of multinomial logit of co-existence options practiced by crop farmers

\begin{tabular}{|c|c|c|c|c|}
\hline Variables & Relative Risk Ratio & Marginal Effect & Std. Error & $\mathbf{P}>|\mathbf{Z}|$ \\
\hline \multicolumn{5}{|l|}{ Resource/Product Exchange } \\
\hline Age (Years) & 10.441 & 0.184 & 9.560 & $0.000 * * *$ \\
\hline Farm experience (years) & 5.692 & 0.132 & 4.731 & $0.006^{*}$ \\
\hline Education & 1.383 & 0.015 & 0.586 & 0.612 \\
\hline Household size (Number) & 1.891 & 0.142 & 0.055 & 0.760 \\
\hline Farm size (ha) & $4.66 \mathrm{e}-06$ & 0.056 & $2.23 \mathrm{e}^{-4}$ & $0.036^{* *}$ \\
\hline Distance to service centers $(\mathrm{km})$ & 2.084 & 0.088 & 0.052 & $0.005^{*}$ \\
\hline Membership of soc. assoc. & 0.051 & 0.097 & 1.156 & $0.038 * *$ \\
\hline Membership of coop. soc. & 0.693 & & 0.804 & 0.835 \\
\hline Income & 1.323 & -5.248 & 0.007 & 0.766 \\
\hline Credit facility & 0.582 & 0.338 & 0.066 & 0.712 \\
\hline Constant & 0.612 & & 0.884 & 0.756 \\
\hline \multicolumn{5}{|l|}{ Entrustment contract } \\
\hline Age (Years) & 0.185 & -0.162 & 0.0591 & $0.001 *$ \\
\hline Farm experience (years) & 1.820 & 0.054 & 2.038 & 0.332 \\
\hline Education & 1.422 & 0.039 & 0.843 & 0.690 \\
\hline Household size (Number) & 1.038 & 0.044 & 0.052 & 0.586 \\
\hline Farm size (ha) & 0.287 & 0.085 & 0.326 & $0.034 * *$ \\
\hline Distance to service centers $(\mathrm{km})$ & 1.068 & 2.202 & 0.054 & 0.154 \\
\hline Membership of soc. assoc. & 0.176 & 0.202 & 0.292 & $0.005^{*}$ \\
\hline Membership of coop. soc. & 0.278 & 0.155 & 0.285 & 0.721 \\
\hline Income & 0.388 & 1.815 & 0.312 & 0.812 \\
\hline Credit facility & 1.224 & -0.916 & 0.280 & 0.692 \\
\hline Constant & 0.588 & & 0.896 & 0.765 \\
\hline \multicolumn{5}{|l|}{ Calves sharing } \\
\hline Age (Years) & 2.194 & 0.046 & 0.205 & $0.065^{* *}$ \\
\hline Farm experience (years) & 0.193 & -0.128 & 1.506 & $0.001 *$ \\
\hline Education (years) & 2.980 & -0.130 & 0.209 & 0.125 \\
\hline Household size (Number) & 1.185 & 0.008 & 3.323 & 0.182 \\
\hline Farm size (ha) & 0.042 & 0.092 & 2.195 & 0.722 \\
\hline Distance to service centers $(\mathrm{km})$ & 9.806 & -0.009 & 0.076 & $0.005^{*}$ \\
\hline Membership of soc. assoc. & 7.116 & 0.083 & 0.264 & 0.884 \\
\hline Membership of coop. soc. & 6.112 & 0.784 & 0.082 & 0.566 \\
\hline Income & 8.121 & 0.065 & 7.524 & $0.006^{*}$ \\
\hline Credit facility & 4.213 & 0.633 & 35.609 & 0.092 \\
\hline Constant & 3.116 & & 0.290 & 0.848 \\
\hline Number of observation (N) & 177 & & & \\
\hline Percent correctly predicted & $84 \%$ & & & \\
\hline Log-likelihood & -168.806 & & & \\
\hline Pseudo $\mathrm{R}^{2}$ & 0.48 & & & \\
\hline
\end{tabular}

(Milk sharing is the base outcome).

Source: Field survey, 2018. ***Significant at 1\%, ** significant at 5\% and * significant at 10\%

From the multinomial analysis, the probability of preference for resources/products exchange as co-existence option was positively and significantly determined by age of respondents, farming experience, farm size and membership in social association. This implies that relative to milk sharing as a practice, a unit increase in age of respondent, farming experience, farm size, and membership of social association increases the chance of practicing this option by $18.4 \%, 13.2 \%, 8.8 \%$ and $9.7 \%$ respectively.

The positive correlation between the choice of resources/products exchange and age of farmer cum years of farming experience might be attributed to the extensive farming knowledge that the sampled crop farmers had gathered over the years in the efficient use of animal manure as an alternative to commercial fertilizers. The cost of inorganic fertilizer is high compared organic fertilizer from animal sources. Experienced crop farmers would be able to efficiently utilize nutrients in manure without degrading water quality. If crop farmers are not willing to accept manure for use as a fertilizer, then sedentary pastoralists will face an ever-increasing problem of how to dispose of the animal waste produced on their farm yards. Increased years of farming experience furnished farmers with more knowledge that increased their rationality in the use of animal manure as an innovation. This is in consonance with the finding of Nnadi and Amaechi (2007) that opined increased years of farming experience as a valuable asset in adoption decision making. 
Total farm size was positive and statistically significant. This could be explained by the fact that large farm size presupposes huge input and labour costs. Therefore, farmers who had large farm size had more disposition to adopt the use of animal manure and traction in farming operations than those who had less. This is in line with the finding of Aklilu and Graaf (2007).

Membership in social association was also positive and statistically significant. This could be attributed to the fact that farmers who were members of many social associations are more likely to have access to greater information and animal resources through their interactions with club members that farmers who were not. This result is consistent with the study of Areghore (2009).

Distance of the farmers' village to market center was found to be statistically significant, but negatively related. A unit increase in the distance between the farmers' village and the market center would likely reduce preference for resource/products exchange option by 5.6\%. This implies that the shorter the distance of the farmer's village to the market center, the easier for him to having access to various animal products. This may be attributed to the fact that relative proximity to market reduces marketing, travelling and transportation costs. Therefore, shorter distance to market and small associated marketing, travelling and transportation costs might be responsible for the higher preference for resource/products exchange option.

From the same Table 3, the age of the respondents, farm size and level of education were found to be statistically significant in determining the probability of preference for cattle entrustment contract as a co-existence option. This implies that relative to milk sharing, a unit increase in age of the respondent, farm size, level of education and membership in social association increases the preference for entrustment contract by $16.2 \%, 8.5 \%$ and $3.9 \%$ respectively. Positive correlation between age of farmer and cattle entrustment contract might be attributed to the fact that older farmers are likely to have learnt the many benefits of investment into livestock enterprises as credible alternatives to majoring in crop cultivation. Investment in livestock enterprise yields about $200 \%$ returns on investment compared to crop farming. It also serves as buffer against crop failure for crop farmers. Additionally, farmers with large farm sizes are often more likely to have bigger harvest and returns from crop farming than farmers with smaller total farm sizes, ceteris paribus. Large farm size presupposes large asset. Thus, farmers who had more assets had more dispositions to diversify into livestock enterprise than those who had less. This finding is equally supported by Fasona et al., (2016) and Aklilu and Graaf (2007).

The positive relationship between the level of education of the respondent and preference for cattle entrustment contract could be attributed to the fact that educated farmers are more analytical and easily observe obvious advantages of diversification into new enterprises (connoting new innovations). This result agreed with the finding of Lemchi et al., (2005).

Results of the multinomial analysis presented in Table 3 also depict that the probability of preference for calves sharing as a co-existence option was positively and significantly related to farmers' age, farming experience and total annual income. Therefore, relative to milk sharing, a unit increase in age of farmer, farm size and annual income increases the chance of a farmer participating in this option by $4.6 \%, 12.8 \%$ and $6.5 \%$ respectively. Calves sharing as a co-existence strategy is synonymous to tenancy fee (isakole in Southwestern Nigeria) paid by tenants (in this study, sedentary pastoralists) to the landowners (in this study, crop farmers). The tenancy fee is paid at intervals to secure the use of land over time. For using a portion of land, a sedentary pastoralist pays a calf every year for using two hectares of land belonging to a crop farmer (landlord). This is a big incentive for a farmer to release his land for the use of pastoralist with a view to promoting peaceful co-existence. The prize of a calf in commodity market is some $200 \%$ in monetary value, more than the returns to a farmer for cultivating two hectares of crops such as maize, millet and cassava (International Crisis Group, 2014).

The longer a farmer is exposed to this great economic benefit, the more he promotes the concept of coexistence with pastoralist who may be willing to settle. This explains the positive relationship between the age of a farmer and his preference for calves sharing. The positive relationship between farm size and preference for calves sharing could be attributed to the fact that farmers who had benefitted from sharing many calves with sedentary pastoralists were more likely to have more money to invest in farming. Such farmers were more likely to have more annual income than their counterparts who are younger, having smaller farm sizes and lower annual income.

\subsection{Determinants of Co-existence practices adopted Sedentary Pastoralists}

Results of the multinomial analysis of co-existence practices adopted by the sampled sedentary pastoralists in the study area are presented in Table 4. As operationalized for crop farmers, milk sharing was taken as the base for comparison.

According to the multinomial analysis, the probability of preference for resource/products exchange as a peaceful co-existence strategy was positively and significantly related to age of pastoralist, herding experience, membership in social association and herd size. This implies that relative to milk sharing, a unit increase in age of pastoralist, herding experience, membership in social association and herd size increases the probability of practicing and/or adopting this strategy by $17.2 \%, 11.6 \%, 14.2 \%$ and $34.4 \%$ respectively. Positive correlation 
between a choice of

Table 4: Results of Multinomial logit of Co-existence options practiced by Sedentary Pastoralists

\begin{tabular}{|c|c|c|c|c|}
\hline Variables & Relative Risk Ratio & Marginal Effect & Std. Error & $\mathbf{P}>|\mathbf{Z}|$ \\
\hline \multicolumn{5}{|l|}{ Resource/Product Exchange } \\
\hline Age (Years) & 12.258 & 0.172 & 7.620 & $0.001 *$ \\
\hline Herding experience (years) & 5.227 & 0.116 & 3.642 & $0.008^{*}$ \\
\hline Education (years) & -1.143 & 0.812 & 0.065 & 0.861 \\
\hline Household size (Number) & 1.782 & 0.056 & 0.166 & 0.612 \\
\hline Distance to service centers $(\mathrm{km})$ & 2.076 & 0.018 & 0.004 & 0.138 \\
\hline Membership of soc. assoc. & 6.068 & 0.142 & 4.109 & $0.002 * * *$ \\
\hline Herd size & 7.930 & 0.344 & 0.832 & $0.006^{* * *}$ \\
\hline Income & 1.324 & -3.248 & 0.612 & 0.715 \\
\hline Ownership of Bank Account & 0.792 & 0.468 & 0.721 & 0.682 \\
\hline Feed composition & 0.822 & 0.422 & 0.826 & 0.827 \\
\hline Constant & 0.582 & & 0.788 & 0.668 \\
\hline \multicolumn{5}{|l|}{ Entrustment contract } \\
\hline Age (Years) & 10.176 & 0.665 & 0.006 & $0.000 * * *$ \\
\hline Herding experience (years) & 1.204 & 0.482 & 0.137 & 0.842 \\
\hline Education (years) & 0.444 & 0.303 & 0.188 & 0.826 \\
\hline Household size (Number) & 0.097 & -0.018 & 0.0306 & 0.615 \\
\hline Distance to service centers $(\mathrm{km})$ & -2.051 & -0.056 & 0.123 & 0.613 \\
\hline Membership of soc. assoc. & 3.462 & 0.126 & 0.056 & $0.042 * *$ \\
\hline Herd size & 0.184 & 0.035 & 0.176 & $0.001 * * *$ \\
\hline Income & 1.866 & 0.126 & 0.184 & 0.756 \\
\hline Ownership of Bank Account & 1.176 & 0.481 & 0.062 & 0.628 \\
\hline Feed composition & 1.568 & -0.014 & 0.014 & 0.139 \\
\hline Constant & 0.618 & & 0.786 & 0.566 \\
\hline \multicolumn{5}{|l|}{ Calves sharing } \\
\hline Age (Years) & 11.618 & 0.102 & 6.242 & $0.000 * * *$ \\
\hline Herding experience (years) & 0.867 & 0.0129 & 0.922 & 0.174 \\
\hline Education (years) & -1.308 & -0.072 & 0.068 & 0.380 \\
\hline Household size (Number) & -0.028 & -0.016 & 0.006 & 0.162 \\
\hline Distance to service centers $(\mathrm{km})$ & 1.367 & -0.092 & 0.612 & 0.167 \\
\hline Membership of soc. assoc. & 0.765 & 0.023 & 1.453 & 0.143 \\
\hline Herd size & 6.026 & 0.636 & 2.733 & $0.001 * * *$ \\
\hline Income & 2.794 & 0.108 & 0.008 & $0.042 * *$ \\
\hline Ownership of Bank Account & 0.668 & 0.018 & 0.816 & 0.724 \\
\hline Feed composition & 0.726 & 0.0188 & 0.765 & 0.625 \\
\hline Constant & 0.678 & & 0.842 & 0.742 \\
\hline Number of observation $(\mathrm{N})$ & 176 & & & \\
\hline Percent correctly predicted & $72 \%$ & & & \\
\hline Log-likelihood & -142.434 & & & \\
\hline McFadden Pseudo $\mathrm{R}^{2}$ & 0.41 & & & \\
\hline
\end{tabular}

Base outcome $=$ Milk sharing (that is, not practised by any respondent).

Source: Field survey, 2018. *** Significant at $1 \%$, ** significant at $5 \%$ and $*$ significant at $10 \%$ resource/products exchange option and age of pastoralist and/or his herding experience could be linked to the fact that older pastoralists are well experienced in the use of crop residues as animal feed in addition to normal pasturage that is weather dependent. Also, sedentary pastoralists that are members of social associations are more likely to have greater access to cheaper sources of improved pastures which produce more dry matter of high nutritive value that can lead to greater animal productivity than do native pastures. This could explain the reason for the positive and significant relationship between resource/products exchange and membership in social association. This is in consonant with the report of Nuru (1996). Positive correlation between resource/products exchange and herd size could be attributed to the fact that sedentary pastoralists with large herd sizes are more likely to be in better synergistic and symbiotic relationship with crop farmers than their counterparts with smaller herd sizes. This is because they possess greater animal products that could be exchanged with products from farmers.

In Table 4 also, the multinomial analysis results show that the probability of preference for entrustment contract as a co-existence practice was positively and significantly related to age of sedentary pastoralist, membership in social association and herd size. Therefore, relative to milk sharing, a unit increase in age, 
membership in social association and herd size increases the chance of practicing this option by $66.5 \%, 12.6 \%$ and $3.5 \%$ respectively. Positive correlation between the choice of entrustment contract and age of sedentary pastoralist and his membership in social association could be attributed to the fact that older sedentary pastoralists who have long settled in the community and are members of the prominent Fulani association (Miyetti Allah Cattle Breeders Association) are more likely to be entrusted with animals by crop farmers, chiefs and other prominent members of the host community. The long established relationships could have wiped out mistrust, hostility and conflicts over resource use. This could also explain the reason for the positive association between entrustment contract and herd size. Sedentary pastoralists who hold cattle in trust for two or more non-pastoralists are likely to have large herd sizes. Sedentary pastoralists that could be linked to a notable association would enjoy the privilege of being entrusted with cattle by non- pastoralists. This explains the positive correlation between entrustment contract and membership of social association.

In Table 4, the probability of preference for calves sharing as a co-existence practice among sedentary pastoralists is positively and significantly related to age, herd size and annual income. Relative to milk sharing, a unit increase in age, herd size and annual income increases the chance of practicing this option by $10.2 \%, 63.6 \%$ and $10.8 \%$ respectively. Positive correlation between calves sharing, pastoralist age, herd size and annual income could be linked to the fact that older sedentary pastoralists are more likely to possess large herd sizes and greater annual income as a result of their long standing and good will in pastoral business. This could give them the privilege of being able to share calves with their hosts in form of tenancy fee ("isakole").

The results of multinomial analysis of the four options practiced by crop farmers and sedentary pastoralists to guarantee peace in the study area over resource use suggest that three strategies are popular: resources/products exchange (the foundation of the symbiotic relationship), cattle entrustment contract and calves sharing. To both agents, cattle entrustment contract is economically rewarding. It serves as saving and insurance against crop failure and unforeseen contingencies for crop farmers. It is an extension of business scope for sedentary pastoralists. Calves sharing serves as tenancy fee paid by sedentary pastoralists for the use of land belonging to crop farmers (land owners).

\section{Conclusion and Recommendations}

In Nigeria as in many other countries in Africa, there has always been a mix of conflict and cooperation between croppers and pastoralists, conflict however has become increasingly likely due to several historical, social, political and environmental factors. These factors have eroded the basis for complementary and symbiotic relationships between the two and increased the potential for goal incompatibility and fatal conflict. Results from this study suggest that crop farmers and pastoralists as economic agents, are capable of effectively managing resources and cooperating for mutual benefit. Local control of natural resources and land is an important factor in making such cooperation possible.

Although fatal conflicts between farmers and pastoralists are common in many parts of the country, it is tempting to try and interpret the relations between the two in terms of a type of ecological determinism: the higher the pressure on resources, the greater the level of conflict. From the results of this study, it is obvious that it is possible for Fulani pastoralists to integrate with the indigenous community and form a cohesive unit for mutual benefit through the practices of resources/products exchange, cattle entrustment contract (caretaking arrangement), calves sharing and milk sharing. Although the participants in this study were randomly selected, the ultimate intention was not to lay claim to exact representativeness for the country but to provide some very important insights on the possibility of harmonious co-existence between croppers and pastoralists to policy makers as well as researchers. The study finds out that crop farmers and sedentary pastoralists could co-exist peacefully by interacting based on exchange of resources and products for mutual benefits. They also live together in peace through the practice of animal entrustment contract (caretaker arrangement) as was commonly practiced by Yoruba women in the past. This practice gives crop farmers and many other non-pastoralists the opportunity of investing into animal husbandry business. It serves as saving and insurance against crop failures for crop farmers. It also serves as expansion of business for pastoralists. Findings here also indicated that, despite some small occurrences of non-violent conflict, indigenous farmers (hosts) in the study area still had remarkable interest in accommodating migrant sedentary pastoralists based on the practice of calves sharing. A calf shared out to a farmer in a year for the use of a portion of land is a huge tenancy (rent) compared to any other form of land use tenancy throughout southwestern Nigeria. The study recommends the following as policy implications of findings:

A national orientation campaign effort is required to inform both the cropper and pastoralist groups of the many benefits of symbiotic relationship between the two.

Matured men rather than small boys should be hired as herders by pastoralists to prevent straying of animals into crop fields.

It is obvious that the national land legislation of 1978 has destabilized the previously stable arrangements that had existed between landowners and tenants. As a result, management of land related conflicts, particularly conflicts between croppers and herders in Nigeria involves various categories of actors or institutions, namely 
individuals, traditional or local groups, state and federal. However, it is recommended that the local institutions be empowered, given socio-political recognition, and some level of control over the private and public lands in their respective jurisdictions.

\section{References}

Adah, O., C. \& Obinne, C.P.O. (2015). Analysis of extent of awareness and adoption of improved oil palm fruit processing technology in Kogi State, Nigeria. Journal of Biology, Agriculture and Healthcare. 5(20):5-10.

Atta-Asamoah, A. \& Aning, K. (2011). Demography, environment and conflict in West Africa ECOWAS and the dynamics of conflict and peace building. In Thomas Jaye and Stella Amadi (Eds) Consortium for Development Partnership (CDD), Dakar, CODESRIA. P. 252.

Awoyelu, F., E. (2017). Analysis of Crop Farmers and Sedentary Pastoralists co-existence and household livelihoods in Oyo and Kwara States, Nigeria. (Unpublished Doctoral Thesis). Obafemi Awolowo University, Ile-Ife, Osun State, Nigeria.

Berns, J. \& Fitzduff, M. (2007). Complementary approaches to coexistence work: what is coexistence and why a complementary approach? Coexistence International, Brandeis University, Massachusetts.

Blench, R. (2010). Conflict between pastoralists and cultivators in Nigeria. Review paper prepared by DFID, Nigeria.

De Haan, C., Dubern, E., Garancher, B. \& Quintero, C. (2014). Pastoralism Development in the Sahel: A Road to Stability? Global Center on Conflict, Security and Development, World Bank.

Fabusoro, E. (2006). A study on property rights, access to natural resources and livelihood security among settled Fulani agro-pastoralists in South-western Nigerian. A project funded by International Foundation for Science, (IFS), Sweden and coordinated by United Nations University Institute of Advanced Studies, Yokohama, Japan; January 2005-June 2006.

Fasona, M., Fabusoro, E., Sodiya, C., Adedayo, V. \& Olorunfemi, F. (2016). Some Dimensions of Farmer's Pastoralists' Conflicts in the Nigerian Savanna. Journal of Global initiatives: Policy, Pedagogy, Perspective. Vol. 10: No. 2, Article 7.

Guyer, J.I. (1997). An African Niche Economy: Farming to Feed Ibadan, 1968-88. Edinburgh: Edinburgh University Press.

Lawal-Adebowale, O.A. (2012). Factors influencing Small Ruminant Production in Selected Urban Communities of Abeokuta, Ogun state. Nigerian Journal of Animal Production, 39(1): 218-228.

Jabbar, M.A. \& Cobbina, J., (1990). Crop-Livestock Interaction for Sustainable food crop production in Tropical Africa. Training course on Sustainable Food Production Systems in Tropical Africa, IITA, Ibadan, 18 June 6 July 1990.

Nuru, S. (1996). Agricultural development in the age of sustainability: livestock production in sustaining the future economic, social and environmental change in Sub-Saharan Africa. The United Nations University, 1996.

Okeke, O.E. (2014). Conflicts between Fulani herders and farmers in Central and Southern Nigeria: discourse on proposed establishment of grazing routes and reserves. International Journal of arts and Humanities. 3(1):6684.

Olaniyi, R.O. (2014). Bororo Fulani Pastoralists and Yoruba Farmers' Conflicts in the Upper Ogun River, Oyo state Nigeria, 1986-2004. Journal of Asian and African studies. DOI: 10.1177/0021909614522948, PP 1-14.

Olufemi, F.J. \& Samson, A.O. (2012) Climate change, environment and conflicts in Nigeria. Brit.J. Arts. Soc. Sci. 6(1): 2046-9578

Pardee, W.D. (2008). Crop farming. Microsoft Encarta 2009 [DVD]. Redmond, WA: Microsoft Corporation.

Sule, A.M., Ogunwale, S.A. \& Atala, T.K. (2002). Factors affecting adoption of fishing innovation among fishing entrepreneurs in Jebba lake community. In: T.A. Olowu (ed.). Journal of Agricultural Extension. 6: 48-60.

Turner, R.M., Marty, A., Bourgeot, A. Ickowicz and Lhoste, P., (2012). Pastoralism en zone seche- Le cas de I'Afrique subsahararienne. Dossier Thermatique du CSFD 9.

Wallenstein, P. (2002). Understanding Conflict Resolution: War, peace and the Global System. London. Sage.

Wehrmann, B. (2008). Land Conflicts - a practical guide to dealing with land disputes. Deutsche Gesellschaft fur Technische Zusammenarbe it (GTZ) GmbH, Germany. 